
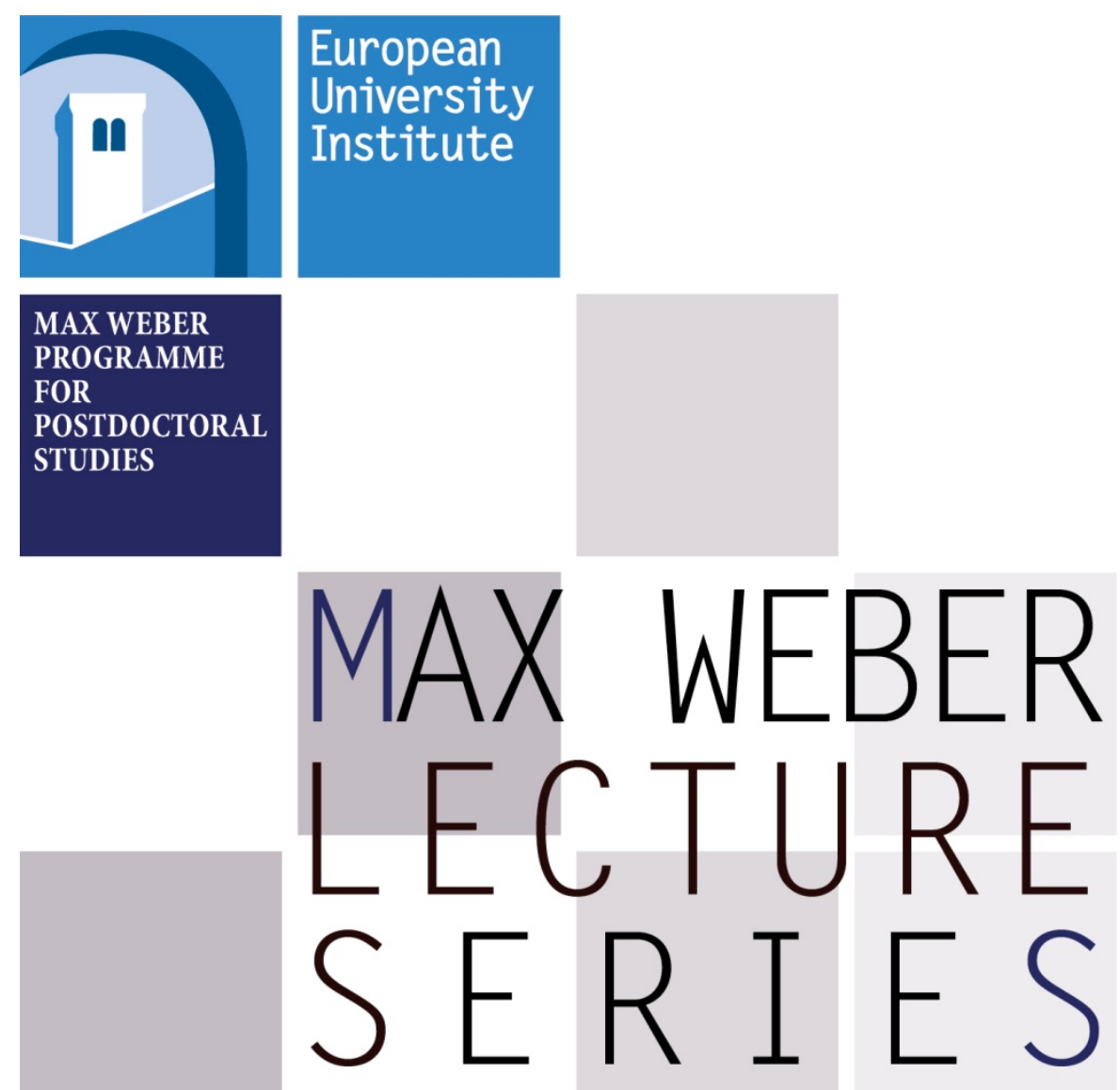

MWP - 2015/02

Max Weber Programme

Human Rights Experimentalism

Gráinne de Búrca 

European University Institute

Max Weber Programme

\section{Human Rights Experimentalism}

Gráinne de Búrca

Max Weber Lecture No. 2015/02 
This text may be downloaded for personal research purposes only. Any additional reproduction for other purposes, whether in hard copy or electronically, requires the consent of the author(s), editor(s). If cited or quoted, reference should be made to the full name of the author(s), editor(s), the title, the working paper or other series, the year, and the publisher.

ISSN 1830-7736

(C) Gráinne de Búrca, 2015

Printed in Italy

European University Institute

Badia Fiesolana

I - 50014 San Domenico di Fiesole (FI)

Italy

www.eui.eu

cadmus.eui.eu 


\begin{abstract}
This paper argues that the way in which international human rights treaty systems function can best be understood through the lens of experimentalist governance theory. Drawing on evidence from the operation of three UN human rights treaties, namely the Convention on the Elimination of Discrimination against Women, the Convention on the Rights of the Child, and the Convention on the Rights of Persons with Disabilities, the paper argues, contrary to many conventional depictions of international human rights regimes as both ineffective and top-down, that they function at their best as dynamic, participatory and iterative two-way systems. Viewing them as experimentalist governance regimes brings to light a set of features and interactions that are routinely overlooked or marginalized in many mainstream accounts of these systems, and suggests possible avenues for reform of other human rights treaty regimes with a view to making them more effective in practice.
\end{abstract}

\title{
Keywords
}

International law, transnational governance, experimentalist governance, human rights regimes, UN treaty regimes, NGOs

An early version of this paper was given as a Max Weber Lecture at the European University Institute in April 2015: "Reframing International Human Rights Regimes", delivered on 22 April 2015. I am grateful to Philip Alston, Nehal Bhuta, Bob Keohane, Chuck Sabel and Joanne Scott for their comments. Funding for this research was provided by the Filomen D’Agostino and Max E. Greenberg Research Fund of NYU Law School.

Gráinne de Búrca

Professor, NYU Law School. 



\section{Introduction}

The disciplines of international law and international relations have long struggled with the difficulty of developing or even imagining a legitimate system of transnational governance which could provide a minimally satisfactory functional substitute for domestic political systems within states. On the one hand, it is widely acknowledged that however attractive the notion of sovereignty remains to states, they are in fact deeply interdependent, and the capacity of separate political communities to govern themselves is fundamentally affected by what other political communities do or do not do, as well as by flows of capital, commerce, persons and ideas. On the other hand, despite this deep interconnectedness, no adequate system of transnational governing capable of meeting the challenges of interdependence has been developed. International institutions largely lack both the capacity and the democratic legitimacy of domestic political institutions, and even the deep experiment in transnational polity-making represented by the European Union has revealed all too starkly the difficulty of developing a democratically legitimate and accepted form of governance beyond the nation state.

One theory which has been developed in recent years, and which offers some response to the dilemmas of transnational governing, is that of experimentalist governance, developed in the work of Charles Sabel and a series of other scholars. Elaborated further below, experimentalist governance is in essence a theory of multi-level governance that proposes a way in which policy can be made and implemented in a multilevel setting, whether domestically, ${ }^{1}$ within firms, ${ }^{2}$ in federal systems, ${ }^{3}$ or, (in more recent scholarship), transnationally. ${ }^{4}$ Amongst the normatively attractive aspects of experimentalist governance theory are its vision of an iterative and participatory system in which policies are developed through the interaction of a series of situated stakeholders and actors in different locations and at different levels across a multilevel system, operating to implement a broadly shared framework, albeit in quite distinct and separate settings.

In this paper I focus on the UN human rights treaty system ${ }^{5}$ and argue that the operation of three treaties in particular - the Convention on the Elimination of Discrimination against Women (CEDAW), the Convention on the Rights of the Child (CRC) and the Convention on the Rights of Persons with Disabilities (CRPD)- can be understood as instances of transnational experimentalist governance. An analysis of the human rights treaty regime through the lens of experimentalism brings to the fore a range of features which are often marginalized or cast as weaknesses in contemporary accounts of the international human rights system, and explains how these features can operate to strengthen the effectiveness of the human rights system and its goals.

Further, an experimentalist reading of the international human rights treaty system provides a robust response to a number of recurrent critiques of that system. Academic and policy literature in recent years has been harshly critical of the international human rights enterprise in general, and of

\footnotetext{
${ }^{1}$ See e.g. Charles Sabel and Michael Dorf “A Constitution of Democratic Experimentalism” (1998) 98 Colum. L. Rev. 267 and C Sabel and William Simon "Minimalism and Experimentalism in the Administrative State" (2011) 100 Georgetown Law Journal 53.

${ }^{2}$ Gary Herrigel, The Embrace of Experimentalism by Manufacturing Multinationals (2014)

${ }^{3}$ C Sabel and W Simon, "Destabilization Rights", C Sabel and M Dorf, "A Constitution of Democratic Experimentalism", see n.1.

${ }^{4}$ G De Búrca, R Keohane and C Sabel, "New Modes of Pluralist Global Governance" (2013) NYU Journal of International Law and Politics, "Global Experimentalist Governance" (2014) British Journal of Politics, C. Sabel and J. Zeitlin, "Experimentalism in Transnational Governance: Emergent Pathways and Diffusion Mechanisms" GREEN (Global Reordering: Evolution through European Networks) Working Paper No. 3 (2011),

${ }^{5}$ While the international human rights regime overall consists of more than the international human rights treaty system, the latter is clearly one of its most important components. Arguably the two other most important elements are the Universal Periodic Review of the Human Rights Council, and the array of international mechanisms created to respond to gross violations of human rights, and particularly the commissions of inquiry.
} 
international human rights norms and treaties in particular. ${ }^{6}$ While such critiques have been advanced for many decades, ${ }^{7}$ their extent and volume in recent years has notably increased. Amongst the various criticisms put forward are (1) the ineffectiveness and lack of impact of human rights treaty systems (2) the ambiguity and lack of specificity of human rights standards (3) the weakness of international human rights enforcement mechanisms (4) the claim to universalism of human rights standards, combined with the hegemonic or top-down imposition of human rights standards on diverse parts of the world.

This paper aims to respond to several of those criticisms by first surveying a body of recent empirical scholarship on the effectiveness of human rights treaties, and secondly by re-interpreting and presenting key aspects of the functioning of those treaties through the lens of experimentalist governance. It begins by outlining how a growing body of recent empirical scholarship challenges the 'ineffectiveness' critique insofar as it identifies a positive correlation, under certain conditions, between the adoption of human rights treaties by states and an improvement in human rights standards within those states. Significantly, most of the studies - both quantitative and qualitative - suggest that the conditions under which human rights treaties are likely to have this positive impact include a degree of political liberalization or democratization within the state in question, and a reasonably active domestic civil society.

Drawing then from evidence of the operation of three specific international human rights treaties, namely the Convention on the Elimination of Discrimination against Women, the Convention on the Rights of the Child, and the Convention on the Rights of Persons with Disabilities, the paper argues that an understanding of the international human rights treaty regime as a transnational experimentalist governance system helps to highlight important features which are routinely underestimated in conventional descriptions and critiques of the system, and to explain how the treaty system might work to improve human rights standards within and across states. Further, when viewed through the lens of experimentalism, two key features of the human rights treaty system which are criticized as weaknesses - namely the apparent ambiguity in standards and the lack of a strong or judicial-type enforcement mechanism - can be seen as important and indeed necessary components of a properly functioning system.

To the extent to which these human rights treaty systems do operate in an experimentalist way, the critiques of universalism and of the hegemonic imposition of centrally determined standards are also unpersuasive. ${ }^{8} \quad$ This is because, where these treaty systems operate experimentally, the openendedness of their human rights standards and the existence of an active domestic civil society facilitates interaction and engagement between locally situated actors who are in a position to translate, localize or vernacularize international standards into domestic and local contexts, ${ }^{9}$ and

\footnotetext{
${ }^{6}$ Prominent recent critics, as the titles of their works reveal, include Samuel Moyn, The Last Utopia (Harvard UP, 2012), Eric Posner, The Twilight of International Human Rights Law (OUP, 2014) and Stephen Hopgood, The Endtimes of Human Rights (Cornell UP, 2014).

${ }^{7}$ Some influential earlier critics include David Kennedy, "The International Human Rights Movement: Part of the Problem?" (2002) 15 Harvard Human Rights Journal 201, and The Dark Side of Virtue: Reassessing International Humanitarianism (Princeton University Press, 2004), and Martii Koskenniemi "The Effect of Rights on Political Culture" in P. Alston, M Bustelo and J Heenan (eds) The EU and Human Rights (Oxford University Press, 1999) and "Human Rights Mainstreaming as a Project of Power" (2006), and Makau Mutua Human Rights: A Political and Cultural Critique , (Penn UP, 2008). For an overview of earlier feminist critiques of human rights, see K. Engle "International Human Rights and Feminisms: When Discourses Keep Meeting" (1992) 13 Michigan Journal of International Law 517 and, more recently, Siobhán Mullally, Gender, Culture and Human Rights (Hart, 2006).

${ }^{8}$ This is certainly not to say that there are no aspects of the international human rights regime that make universalist claims or that operate in a hegemonic or top-down way. The invocation and use by international financial institutions and donors of international aid of human rights standards may well at times do so, and forcible humanitarian intervention in alleged defence of human rights may also do so. The focus of this paper, however, is the functioning of the international human rights treaty system, (focusing specifically on CEDAW, CRC and CRPD) which I argue in many respects can be understood as an experimentalist governance system which is neither hegemonic/top-down nor universalist in its claims.

${ }^{9}$ For elaboration of the ideas of localization and vernacularization, see Sally Engle Merry, Peggy Levitt, Mihaela Rosen and Diana Yoon "Law from Below: Women's Human Rights and Social Networks in New York City" (2010) 44 Law \&
} 
international actors and institutions which rely for local knowledge, feedback and enforcement on them. The paper argues further that the findings of the empirical studies - namely that there is a positive correlation between the existence of an active civil society and the effectiveness of a human rights treaty which the state has ratified - bolster the argument that it is the experimentalist functioning (even if not the design ${ }^{10}$ ) of these human rights treaty systems that helps to account for their positive impact. Understanding the operation of human rights treaties as experimentalist governance may also have practical implications about where future research and resources might be directed in terms of strengthening the effectiveness of the human rights system in improving the lives of human beings across the globe.

\section{The effectiveness of human rights treaties}

A recent critique of the international human rights treaty system argues that the array of empirical studies, which have been carried out on a range of human rights treaties using a selection of different measurements and methods, do not reveal any consistent results, and that even those which show positive results are "cautious in their findings", such that there can be "little confidence that the treaties have improved people's lives". ${ }^{11}$ A closer reading of the various studies, however, indicates that they do not actually differ very much, if at all, about the circumstances in which, and the conditions under which, human rights treaty ratification correlates with an improvement in human rights standards. ${ }^{12}$ It is certainly true that some of the earlier studies, including those carried out by Linda Keith in $1999^{13}$, Oona Hathaway in $2002^{14}$ and Emilie Hafner Burton and Kiyoteru Tsutsui in $2007^{15}$ appeared to suggest that treaty ratification does not lead to an improvement in human rights performance by states and may even be associated with a dis-improvement in standards. However, various limitations of these studies have been noted, which qualify their findings. ${ }^{16}$ In particular, the

(Contd.)

Society Review 101, Sally Engle Merry and Peggy Levitt "Vernacularization on the Ground: Local Uses of Global Women's Rights in Peru, China, India and the United States' (2009) 9 Global Networks 441 and Sally Engle Merry and Rachel Stern "The Female Inheritance Movement in Hong Kong: Theorising the Local/Global Interface" (2005) 46 Current Anthropology 387.

${ }^{10}$ While the CRPD was consciously drafted in a novel and more broadly participatory way to include features I have described as experimentalist (see G. de Búrca “The EU in the Negotiation of the UN Disability Convention' (2010) 35 European Law Review 174), the CRC and CEDAW were not originally so designed but have come to develop many of these features, including in particular a much more substantial and active role for the relevant civil society groups, networks and institutions at all levels of the treaty-body system and its implementation.

${ }^{11}$ E Posner, The Twilight of Human Rights, p 78.

12 The argument advanced by Emilie Hafner Burton and James Ron in "Seeing Double: Human Rights Impact Through Qualitative and Quantitative Eyes" (2009) 61 World Politics 360 to the effect that qualitative studies tend to suggest a more optimistic and positive impact of human rights treaties while the results of quantitative studies are more skeptical perhaps implying selection bias on the part of those conducting qualitative studies - has been rebutted by Beth Simmons in "From Ratification to Compliance: Quantitative Evidence of the Spiral Model" in Thomas Risse, Stephen Ropp and Kathryn Sikkink, The Persistent Power of Human Rights (CUP, 2012), Chapter 3, and Xinyuan Dai, "The Compliance Gap and the Efficacy of International Human Rights Institutions" in Chapter 5 of the same volume, as not being borne out by the various studies cited. Simmons found no relevant difference between the findings of the different kind of studies, while Dai pointed to the negative findings of some qualitative studies and the positive findings of some quantitative studies.

${ }^{13}$ L Keith "The United Nations International Covenant on Civil and Political Rights: Does It Make a Difference in Human Rights Behavior?" (1999) 36 Journal of Peace Research 85

${ }^{14}$ O. Hathaway “Do Human Rights Treaties Make a Difference?” (2002) 111 Yale Law Journal 1935

${ }^{15}$ E. Hafner Burton and K Tsutsui "Justice Lost! The Failure of International Human Rights Law to Matter Where Needed Most” (2007) 44 Journal of Peace Research 407.

${ }^{16}$ For a critique of the methodology, theoretical framework and policy prescriptions of the Hathaway study see R. Goodman and D Jinks "Measuring the Effects of Human Rights Treaties" (2003) 14 European Journal International Law 171. Yonatan Lupu, in "The Informative Power of Treaty Commitment: Using the Spatial Model to Address Selection Effects" (2013) 57 American Journal of Political Science 912 argues that the findings of scholars including Hathaway, Hafner-Burton and Tsutsui that the human rights practices of some states worsened after ratification of the ICCPR and 
suggestion that there is a correlation between ratification of human rights treaties by states and a disimprovement in human rights standards has since then been repeatedly challenged and confronted with contrary evidence. ${ }^{17}$

Beth Simmons argues that the earlier studies adopt a homogenous approach to treaty ratification without either specifying any of the conditions under which states ratified them and without differentiating between the types of regime in the states in question. ${ }^{18}$ Xinyuan Dai points out that the findings drawn from the studies suffer from various conceptual and methodological problems, including the limitations of the sources used by the authors to measure compliance with rights, the failure to distinguish between different kinds of treaty obligations, and differences in the indicators used..$^{19}$ Dai also makes a critique similar to that of Simmons, namely the failure of these earlier studies to specify the conditions under which Treaty ratification does or does not have an impact. ${ }^{20}$ Of the apparently different results yielded by a range of empirical studies, she comments that "the "optimists" do not believe naively that international human rights law is a magic bullet, but they seek to understand the factors and contexts that enable law's effect. Likewise, the "pessimists" know that international human rights law works some times, but not as much as they believe it should. Rather than debating over the extent to which international human rights law matters, what is more urgent is to first understand why and how and under what conditions should it matter". ${ }^{21}$

A range of more recent empirical studies, which appear to have followed this advice, point to a clear correlation between human rights treaty ratification and an improvement in human rights standards where there is a reasonably active civil society within the states in question. Eric Neumayer in a 2006 study found that ratification of human rights treaties - including a range of regional as well as international human rights treaties - did improve human rights, conditional on the strength of civil society and the existence of democratic regimes in the states in question. In a wide-ranging and rigorous book-length study published in 2009, Beth Simmons found that one of the crucial ways in which international human rights treaties improved human rights standards - particularly in transitional democracies - was their mobilization of domestic constituencies with an interest in invoking and enforcing the obligations contained in the treaties. ${ }^{22}$ These findings have been further bolstered by other quantitative and qualitative studies concerning specific human rights treaties and

(Contd.)

the Convention against Torture, and suggests these findings may have been due to insufficient accounting for selection effects.

${ }^{17}$ See Christopher Fariss "The Changing Standard of Accountability and the Positive Relationship between Human Rights Treaty Ratification and Compliance" (2015) British Journal of Political Science, forthcoming. See also Y.Lupu, "The Informative Power of Treaty Commitment: Using the Spatial Model to Address Selection Effects" ibid.

${ }^{18}$ Beth Simmons "From Ratification to Compliance: Quantitative Evidence of the Spiral Model" in Thomas Risse, Stephen Ropp and Kathryn Sikkink, The Persistent Power of Human Rights (CUP, 2012), Chapter 3.

${ }^{19}$ Xinyuan Dai "The Conditional Effects of International Human Rights Institutions" (2014) 36 Human Rights Quarterly 569. Eric Neumayer in "Do International Human Rights Treaties Improve Respect for Human Rights" (2005) 49 Journal of Peace Studies 925 similarly criticizes the mismatch between the treaties whose ratification was selected for examination in these studies and the substantive rights whose protection the studies were seeking to assess.

${ }^{20}$ X. Dai "The Compliance Gap and the Efficacy of International Human Rights Institutions" in The Persistent Power of Human Rights, ibid, Chapter 5.

${ }^{21}$ X. Dai, “The Conditional Effects of International Human Rights Institutions” n. 19 above.

${ }^{22}$ Beth Simmons, Mobilizing for Human Rights (CUP, 2009). See e.g. at p 371, 378: "one of the lessons that follows from the research in this book is the crucial role that domestic actors play in their own human rights fate. Rights stakeholders around the world have actively made decisions about when and how to employ the norms contained in human rights treaties to influence practices on the ground in their countries. Sometimes they have done this with outside help but the locals are the ones who carry the ball and take the risks. They also make decisions about what is culturally appropriate in their society and how best to deploy limited resources in order to realize the greatest benefits from the promises of the human rights treaties their governments have signed... The most important policy advice that comes from this study.. is domestic ownership. Human rights treaties matter where local groups have taken up the torch for themselves". 
regions. ${ }^{23}$ In a time series cross-sectional analysis of CEDAW (which is presented as a least likely case given the massive social and institutional changes mandated by the treaty without providing any resources or incentives beyond those of other human rights treaties), Neil Englehart and Melissa Miller have argued that it is the domestic dynamics set in motion by the process of treaty ratification that account for the effectiveness of the treaty in bringing about social change, particular in relation to women's political and social rights. ${ }^{24}$ Similarly Xinyuan Dai, in a qualitative study of the impact of the Helsinki Final Act on the transformation of state behavior and social change within the Soviet bloc finds that the crucial factor was the way in which the international agreement strengthened the leverage and information of domestic constituencies and activists. Other qualitative studies which reinforce the conclusion that the interaction between domestic constituencies and civil society is crucial in explaining the positive effect of human rights treaties include Suzanne Zwingel's comprehensive study of the operation of CEDAW, ${ }^{25}$ and Jasper Krommendijk's study of the impact of ratification of various human rights treaties in a range of democratic states. ${ }^{26}$

Some have described the growing emphasis on statistical measurement in the social sciences as an obsession with measurement, and the various limitations of the quantitative studies on the impact of human rights treaty ratification have been pointed out. ${ }^{27}$ Hariss, for example, argues that the results of several quantitative studies are skewed by the failure to take into account the gradual ratcheting up of the standards to which states are being held by the operation of the treaty-body system. ${ }^{28}$ Risse and Sikkink point out that statistical surveys of the human rights compliance of states miss out changes in the behavior of important non-state actors like large corporations, ${ }^{29}$ which are important both as violators and as potential promoters of human rights. ${ }^{30}$

${ }^{23}$ Daniel Hill in "Estimating the Effects of Human Rights Treaties on State Behaviour" (2010) 72 The Journal of Politics 1161 found considerable variance between the results found in relation to the Convention against Torture on the one hand and CEDAW on the other and suggested that more treaty-specific theorizing may be needed:

${ }^{24}$ N. Englehart and M Miller "The CEDAW effect: International Law's Impact on Women's Rights” (2014) 13 Journal of Human Rights 22. They find less evidence of positive impact in the case of women's economic rights. See also the study carried out by Seo Young Cho, "International Women's Convention, Democracy and Gender Equality" (2014) 95 Social Science Quarterly 719, suggesting that the interaction of democracy with the Convention is significant in advancing women's social rights.

${ }^{25}$ S Zwingel How do International Women's Rights become Effective Domestic Norms? An Analysis of the Convention on the Elimination of all Forms of Discrimination against Women PhD thesis, Bochum (2005) and more recently "How Do Norms Travel? Theorizing International Women's Rights in Transnational Perspective" (2012) 56 International Studies Quarterly 115. See also the study by Sally Engle Merry of the impact of the CEDAW, looked at in particular through the lens of the state reporting system, as well as at the issues on which states resist the impact of the treaty: "Gender Justice and CEDAW: The Convention on the Elimination of All forms of Discrimination against Women" (2011) 9 Journal of Women of the Middle East and the Islamic World 49 and "Human Rights Monitoring, State Compliance and the Problem of Information" forthcoming in Simmons and Goodman (eds). See also the study done by Andrew Byrnes and Marsha Freeman The Impact of the CEDAW Convention: Paths to Equality. A Study for the World Bank (World Development Report: Gender and Development, 2011).

${ }^{26} \mathrm{~J}$ Krommendijk The domestic impact and effectiveness of state reporting under UN Human Rights Treaties in the Netherlands, New Zealand and Finland (Intersentia, 2014). In his chapter on CEDAW, the author finds that the effectiveness of the 'concluding observations' of the human rights treaty bodies are not the result of a compliance pull from the committee or treaty body itself, but rather are attributable to the mobilization and lobbying of NGOs and the attention given in domestic parliaments to the concluding observations. (p 198). Similarly, with regard to his findings on the CRC and its impact in the Netherlands, he states in his concluding chapter that the effectiveness of the concluding observations of the committee of the CRC is to be "attributed to the crucial role of domestic NGOs who organized themselves in the Dutch Children's Rights Coalition”.

${ }^{27}$ Debra Liebowitz and Suzanne Zwingel, "Gender Equality Oversimplified: Using CEDAW to counter the Measurement Obsession" (2014) 16 International Studies Review 362. They argue in particular that the long slow dialogic nature of the change that took place in Colombia in relation to reproductive rights on account of would be missed out by many of the statistical surveys.

${ }^{28}$ C Fariss, n. 17 above.

${ }^{29}$ For an example of human rights training and compliance brought about by other kinds of non-state actor, see the work of the International Rescue Committee in refugee camps: Y Hutchinson "The Transference of Gender-Based Norms in the 
Nevertheless, despite these and other limitations of statistical evidence, there is unquestionably a growing body of empirical evidence, both quantitative and qualitative, which points to the fact that the signing and ratification of international human rights treaties by states which are politically liberalized (or in transition towards political liberalization) and have a reasonably active civil society is associated with a subsequent improvement in human rights standards in those states. ${ }^{31}$ More recent studies argue that this may be true also even in repressive states. ${ }^{32}$ This body of literature confronts the criticism that the human rights treaty system is ineffective, and demonstrates that in circumstances where there is some degree of political liberalization and the presence of an active civil society, the impact of human rights treaty ratification can be effective in improving life conditions and human rights standards in the ratifying states.

The next section analyses a number of international human rights treaties through the lens of experimentalist governance theory. The paper goes on to suggest that the experimentalist functioning of these treaty systems may help to explain the correlation between the effectiveness of human rights treaties and the presence of an active civil society identified in the empirical literature outlined above.

\section{International human rights treaties through the lens of experimentalist governance}

\section{(a) Experimentalism as a theory of transnational governance}

The idea of experimentalist governance as a theory of multilevel governance has been introduced above. $^{33}$ Inspired by Deweyan ideas of pragmatic learning from experience, the insights of experimentalism have been applied to a range of settings of multi-level governing, including within the firm, within federal states, as well as between states within transnational polities such as the EU, and more recently in the transnational setting.

With its central emphasis on the importance of adequate stakeholder participation, experimentalist governance theory is premised on the belief that an effective and deliberative system of multilevel governing can evolve or be developed where a number of key features are present. The five key features, outlined in earlier scholarship, ${ }^{34}$ are: 1) initial reflection and identification of a broadly shared perception of a common problem, one that is shared across diverse participating units or states, resulting in 2) the articulation of a framework understanding with open-ended goals; 3 ) implementation of these broadly articulated goals by contextually situated or 'lower level' actors, entailing the active participation of key stakeholders who have knowledge of local conditions and discretion to adapt the framework norms to these different contexts; 4) continuous provision of feedback to the 'center' from local contexts and by relevant stakeholders, allowing for reporting and monitoring across a range of contexts, with outcomes subject to non-hierarchical or peer review; 5) periodic and routine re-evaluation (and, where appropriate, revision) of goals and practices in light of the results of the ongoing review and in light of the shared purposes.

Experimentalist Governance regimes sometimes also operate in the shadow of a background system or a threatened sanction which can be called a "penalty default". A penalty default is an

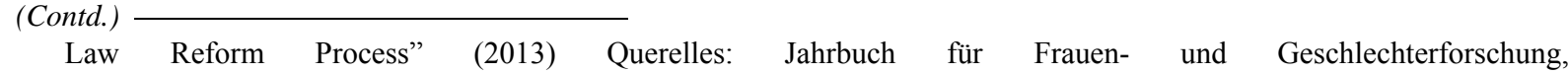
http://www.querelles.de/index.php/qjb/article/view/6/17

${ }^{30}$ T Risse and K Sikkink, The Persistent Power of Human Rights (2012)

${ }^{31}$ See also Courtenay Conrad and Emily Hencken Ritter "Treaties, Tenure, and Torture: The Conflicting Domestic Effects of International Law" (2013) 75 Journal of Politics 397

32 On how to take account of changes in the repressive nature of a state for the purposes of measuring human rights compliance, see Keith Schnakenberg and Christopher Fariss "Domestic Patterns of Human Rights Practices" (2014) 2 Political Science Research and Methods 1. See also the argument of Heather Smith-Cannoy, based on both quantitative and qualitative analysis, that even within insincere and somewhat repressive states such as Tajikistan, Kyrgystan and Hungary, the presence of active domestic groups and their use of complaints systems set up under UN human rights treaties can lead to important change: Insincere Commitments: Human Rights Treaties, Abusive States and Citizen Activism (Georgetown UP, 2012)

${ }^{33}$ See notes 1-4 above.

${ }^{34}$ This synopsis is taken from G de Búrca, R Keohane and C Sabel "Global Experimentalist Governance" (2014) British Journal of Politics
} 
outcome which may serve to incentivize cooperation by applying sanctions in the case of failure to cooperate. In the context of the international human rights system, a penalty default might exist in the form of a state or states making delivery of aid conditional on compliance with human rights norms, or consumer-organized boycotts of goods from countries which seriously violate human rights standards. ${ }^{35}$

A transnational governance system comprising the five elements outlined - namely general agreement on framework goals, broad participation through devolution of discretion in implementation to locally or contextually situated actors, with continuous feedback through monitoring and reporting to the center, and periodic revision of framework goals in the light of experience gathered through the reporting and monitoring process - constitutes an experimentalist governance system. The hypothesis of experimentalist governance theory is that where all five of these features are present and operate together, they should foster a normatively desirable form of deliberative and participatory governance. Experimentalist governance theory thus aims to address the conundrum of how to create an adequate and legitimate transnational governance system which takes seriously both the existence of common or collective problems shared by states and the deep diversity - of many kinds - of different political systems and communities. It recognizes that transnational governance requires shared agreement on broad goals, but simultaneously recognizes that the way these goals are fleshed out and implemented will vary - perhaps significantly - from context to context and from state to state. Experimentalist governance theory also emphasizes the importance of stakeholder participation in an informed and effective policy, and the importance of ensuring accountability through regular and transparent nonhierarchical review.

(b) The international human rights treaty system as experimentalist governance

The UN human rights treaty system began with the Universal Declaration of Human Rights and was followed by a series of core 'implementing treaties' that have been adopted in the decades since. There are by now around ten (depending on how they are counted), the main treaties being the two Covenants, namely the International Covenant on Civil and Political Rights and the International Covenant on Economic Social and Cultural Rights. In addition to these are the Convention on the Elimination of Racial Discrimination, the Convention against Torture, the International Convention on the Rights of All Migrant Workers, the International Convention for the Protection of All Persons from Enforced Disappearances, as well as the CEDAW, CRC and CRPD already mentioned above. The empirical research on which the argument of this paper rests is based on the latter three treaties, which share a set of features common to experimentalist governance processes. ${ }^{36}$ For present purposes, I make no claim about the other treaty systems, although it seems probable that several of them share at least some relevant features and aspects of experimentalist governance systems.

Each UN human rights treaty generally encompasses a set of human rights norms which articulate a set of rights focused either on particular communities: women, children, persons with disabilities; or on particular issues, whether a broad set of civil and political rights or economic and social rights, or a more specific set of issues such as race discrimination, torture or disappearances. The treaties usually establish an organ known as a 'treaty body'. This body is a committee of independent experts who - unlike the members who compose the Human Rights Council - are not representatives of national governments but are generally nominated and selected because they are believed to have relevant expertise on the issues raised by the rights in question and to be independent

\footnotetext{
${ }^{35}$ See for a study, Simone Dietrich and Amanda Murdie "Human Rights Shaming through INGOs and Foreign Aid Delivery" (2015) http://papers.ssrn.com/sol3/papers.cfm?abstract_id=2641766

${ }^{36}$ Regional human rights treaty systems such as the European Convention on Human Rights, the Inter-American Human Rights system and the African Human Rights system are also not included within the scope of the present paper, although some of them share a number of features of experimentalist governance. For analyses of the ECHR which emphasize the open-endedness of standards and the lack of strictly hierarchical or top-down authority see N. "The Open Architecture of European Human Rights Law" (2008) 71 Modern Law Review 183 and O. de Schutter and F Tulkens "The European Court of Human Rights as a pragmatic Institution" in E Brems (ed) Conflicts Between Fundamental Rights (Intersentia, 2008) 169.
} 
from any government or from political interference. ${ }^{37}$ States are required under the treaties to make periodic reports to the treaty body on their progress in implementing the commitments undertaken in the conventions, and the treaty body is empowered to make recommendations and address observations to the states based on their consideration of the reports.

Human rights treaty systems feature the five core elements of experimentalist governance in the following ways. First, they are premised on a general consensus amongst the signatory states that it is important to guarantee protection for this set of human entitlements; second, they articulate a set of rights in fairly broad, flexible and general terms on which state signatories have been able to reach consensus; third, they allow for significant discretion on the part of states and related actors as to how to implement and realise these rights in practice; fourth, they establish a system of periodic reporting, monitoring and feedback, under which states are obliged to report regularly on their compliance with the obligations undertaken in the treaty, which is followed by a non-hierarchical and formally nonbinding process of review in the form of the treaty-body procedure. This procedure involves a specialist committee of experts receiving information, observing, reviewing and making recommendations to states in response to reports made to them. The fifth feature of experimentalist governance systems, namely the iterative dimension which allows for periodic and reflexive reconsideration and (where appropriate) revision of goals, is less obvious in the context of international human rights treaty systems, but there are in fact important elements of iteration and reconsideration, as well as revision, within these too. This will be elaborated in more detail below in the descriptions of the functioning of the CEDAW, CRC and CRPD. The other crucial experimentalist dimension which has developed in more recent decades and which was mostly absent from the original human rights treaties - with the exception of the most recently drafted Convention on the Rights of Persons with Disabilities - is a key role for stakeholders - including civil society actors, NGOs, national human rights institutions and other networks - in the process of monitoring and reporting to the treaty bodies, and increasingly also in national as well as international monitoring and implementation.

The absence until recently of this important dimension, namely a key role for civil society in many aspects of the functioning of the treaty regime, is one of the main reasons why the international human rights system has not generally been viewed as an experimentalist system. ${ }^{38}$ The growing role of civil society actors, the emergence of national human rights institutions as part of the treaty-body monitoring system, and the creation of transnational and regional networks of NGOS to support the treaty-body system has been a fairly gradual development over time, and one which has evolved considerably since most of the regimes were first established. ${ }^{39}$ Indeed, while there is some evidence

\footnotetext{
${ }^{37}$ For overviews and analyses of the treaty system, see H Keller and G Ulfstein, UN Human Rights Treaty Bodies: Law and Legitimacy (Cambridge UP, 2015); S Egan, The UN Human Rights Treaty System: Law and Procedure (Bloomsbury, 2011); M. Cherif Bassiouni and W Schabas, New Challenges for the Human Rights Treaty Machinery (Intersentia, 2011), A Bayefsky, Enforcing Human Rights Law: The UN Treaty System in the 21 $1^{\text {st }}$ Century (Kluwer, 2000); P Alston and J Crawford (eds) The Future of UN Human Rights Treaty Monitoring (Cambridge UP, 2000).

${ }^{38}$ For an earlier critique of the human rights treaty body system calling for more active participation for NGOs within the treaty-body system and calling for other related reforms, see A Clapham "UN Human Rights Reporting Procedures: An NGO Perspective" In P Alston and J Crawford (eds) The Future of UN Human Rights Treaty Monitoring (Cambridge UP, 2000). While there is a large body of academic literature on the subject of reform of the treaty-body system, there has been only a marginal emphasis on the role of civil society. See e.g. the single chapter on civil society in a 17-chapter book, P Lynch and B Schokman "Taking Human Rights from the Grassroots to Geneva and Back: Strengthening the Relationship between UN Treaty Bodies and NGOs", Chapter 9 in M. Cherif Bassiouni and W. Schabas and New Challenges for the UN Human Rights Machinery: What Future for the Treaty Body System and the Human Rights Council Procedures (Intersentia 2011).

${ }^{39}$ A number of important studies have focused on the growing role of transnational networks of NGOs in promoting human rights, e.g. T. Risse, S. Ropp and K. Sikkink, The Persistent Power of Human Rights (CUP, $2^{\text {nd }}$ edn, 2013, $1^{\text {st }}$ edn, 1999), M. Keck and K. Sikkink, Activists Beyond Borders: Advocacy Networks in International Politics (Cornell UP, 1998), and E. Hafner-Burton, Making Human Rights a Reality (Princeton UP, 2013). On the growing role of national human rights institutions, see R.Goodman and T. Pegram, Human Rights, State Compliance and Social Change (CUP, 2012). Even recent critics of Risse et al's "boomerang" theory and of the role of international networks and NGOs in shaming and mobilizing opposition to a government's policy, who have pointed to the problems of backlash and corruption that can
} 
of a role for civil society being envisaged when the Children's Rights Convention was being drafted in the $1980 \mathrm{~s}^{40}$ which was due in part to the unusually central involvement of NGOs in the drafting process $^{41}$ and in the inclusion of the very obliquely worded Article 45 of the Convention, ${ }^{42}$ the same was not originally true for the CEDAW treaty which was adopted a decade earlier, where the drafting process was not formally open to civil society groups and partly as a reflection of that fact no provision of CEDAW envisages a role for NGOs. ${ }^{43}$ The same is true for the two Covenants, namely the International Covenant for the protection of Civil and Political Rights and the International Covenant for the Protection of Economic, Social and Cultural Rights (which are not considered in detail in this paper): no initial provision was made for any explicit role for civil society within those systems, although such a role has grown up in the context of those two treaties too. ${ }^{44}$ By comparison the Convention on the Rights of Persons with Disabilities, which is the most recent of the UN human rights treaties, explicitly and notably builds in a central and active role for civil society, and particularly for organizations of persons with disabilities and their representatives. ${ }^{45}$

The argument that UN human rights treaties can be seen as examples of transnational experimentalist governance is based on information gathered on the operation of three particular human rights treaty systems, namely the CRPD, CRC and CEDAW. Similar research has not yet been undertaken in relation to the other UN human rights treaty systems, including the two Covenants, although it seems probable that a similar hypothesis about the growing role of civil society in the functioning of these regimes could also be advanced.

A comprehensive analysis of the experimentalist features of the CRPD regime has already been provided elsewhere, ${ }^{46}$ and for the purposes of this paper I will refer to that analysis when discussing the CRPD, and will concentrate the more detailed description of experimentalist features here mainly on the CEDAW and CRC regimes. Recall that the five key features are: initial identification of a shared perception of a common problem; general agreement on framework goals;

(Contd.)

ensue, have also argued that the backlash problem could be avoided if local actors were more involved, taking ownership and leadership of the issue as much as possible, being careful not to be pressurized too much by international actors and media at a pace that outstrips and in a way that exacerbates the domestic crisis: see Rochelle Terman, "Backlash: The Unintended Consequences of Western Human Rights Intervention” (2013, Democracy Now! http://www.democracynow.org/).

${ }^{40}$ Cynthia Price Cohen "The Role of Nongovernmental Organizations in the Drafting of the Convention on the Rights of the Child" (1990) Human Rights Quarterly, Vol. 12 pp. 137-147, and Joan Fitzpatrick, "United Nations Convention on the Rights of the Child: Toward Adoption of the United Nations Convention on the Rights of the Child: A Policy-Oriented Overview" 83 American Society of International Law Proceedings 155, 162 (1989).

${ }^{41}$ In 1983, several years into the drafting process, a number of NGOs aligned to form the NGO Ad Hoc Group on the Drafting of the Convention of the Rights of the Child: see S.N. Hart, "Non-Governmental Efforts Supporting U.S. Ratification of the Convention on the Rights of the Child" 4 Loyola. Poverty Law Journal 141, 145 (1998).

${ }^{42}$ Article 45 of the CRC provides that the Committee "may invite specialized agencies, [UNICEF] and other competent bodies ... to provide expert advice on the implementation of the Convention in areas falling within the scope of their respective mandates".

${ }^{43}$ The provision corresponding to Article 45 of the CRC is Article 22, which provides only that "The [UN] specialized agencies shall be entitled to be represented at the consideration of the implementation of such provisions of the present Convention as fall within the scope of their activities. The Committee may invite the specialized agencies to submit reports on the implementation of the Convention in areas falling within the scope of their activities" and makes no reference to 'other competent bodies'.

${ }^{44}$ See A. Clapham, n. 38 above, and Rachel Brett "The Role and Limits of Human Rights NGOs at the United Nations" (1995) XLIII Political Studies 96

${ }^{45}$ See e.g. G de Búrca, "The EU in the Negotiation of the UN Disability Convention" (2010) 35 European Law Review 174, T. Melish "The UN Disability Convention: Historic Process, Strong Prospects, and Why the U.S. Should Ratify", 14 Human Rights Brief. 37 (2007) and F. Mégret "The Disabilities Convention: Towards a Holistic Conception of Rights" International Journal of Human Rights, Vol. 12, No. 261, 2008

${ }^{46}$ See G. de Búrca, R.O. Keohane and C. Sabel, "New Modes of Pluralist Global Governance" (2013) 45 NYU Journal of International Law and Politics, 723, part III; and G de Búrca, "The EU in the Negotiation of the UN Disability Convention", ibid. 
continuous feedback through monitoring and reporting to the center; and periodic revision of framework goals in the light of experience gathered through the reporting and monitoring process.

\section{(1) Experimentalist features of the UN human rights treaty systems}

The first two elements are fairly readily visible in the case of most human rights treaties, and certainly in relation to each of the three human rights treaties under consideration here. In terms of the first feature, states come together in an intergovernmental conference or under the auspices of the UN because a significant number of them believe that it is necessary to provide more specific international legal protection for certain vulnerable groups or constituencies such as women, children, persons with disabilities. In other words there is a broad, albeit thin, consensus on the existence of a common problem on which a group of states is willing to commit themselves under international law to a strategy for addressing the problem.

In terms of the second feature, human rights treaties such as the CEDAW, CRC and CRPD are quintessentially broad agreements on framework goals. The rights set out in the treaties are expressed in broad and open-ended terms which call for considerable interpretation and elaboration in order to be implemented in practice. The key provision of CEDAW, for example, prohibits discrimination against women and defines the concept of discrimination in Article 1 very broadly, ${ }^{47}$ and does not actually define the core concept of gender equality on which the Convention is based. Similarly the Convention on the Rights of the Child, after setting out a general obligation on states in Article 4 to "undertake all appropriate legislative, administrative and other measures for the implementation of the rights recognized in the present Convention" goes on to stipulate the substantive rights in the very broad and flexible terms characteristic of human rights treaties. Thus for example, to take two key provisions, Article 6 provides that "every child has the inherent right to life" and Article 12(1) provides that "states parties shall assure to the child who is capable of forming his or her own views the right to express those views freely in all matters affecting the child". In the case of the Convention on the rights of Persons with Disabilities, core terms such as 'disability' 'discrimination' and 'reasonable accommodation' were deliberately defined in broad and open-ended ways. ${ }^{48}$

The third and fourth features of an experimentalist system are the devolution of discretion in implementation to locally or contextually situated actors, with continuous feedback being provided through a process of monitoring and reporting to the center. Each of these elements is fairly evident in the human rights treaty system, since states are left largely to their own devices in terms of the specific ways in which they choose to comply with their commitments and obligations under the Conventions, and are given broad discretion as to who will be responsible for the implementation of which obligations. The provision of feedback to the center is evident in the institution of the treaty-body system and the requirement of periodic reporting, which generally results in a form of dialogue between states and the committee members. However, the crucial development which has imbued these third and fourth elements - which could otherwise remain a limited, formalistic and bureaucratic exercise - with a distinctly experimentalist flavor is the growing participatory dimension. Even if the CEDAW and CRC treaties, unlike the CRPD, made no mention of civil society in their express terms and appear to leave the task of implementation, monitoring and reporting entirely in the hands of the signatory states, the reality has become something quite different over time.

(2) The growing participatory dimension of UN human rights treaty systems

Given the importance of this growing participatory dimension of the human rights treaty system to the emergence of an experimentalist regime, the development will be outlined in greater detail here,

\footnotetext{
${ }^{47}$ Article 1 provides that "the term 'discrimination against women' shall mean any distinction, exclusion or restriction made on the basis of sex which has the effect or purpose of impairing or nullifying the recognition enjoyment or exercise by women, irrespective of their marital status, on a basis of equality of men and women, of human rights an fundamental freedoms in the piolitical, economic, social, cultural, civil or any other field'. For a detailed discussion of the drafting of the CEDAW, see $\mathrm{S}$. Zwingel, PhD thesis, n.25 above.

${ }^{48}$ For a discussion, see G. de Búrca, n.10 above.
} 
before returning to explain how the experimentalist account of the treaty system effectively responds to several of the critiques of the human rights system outlined above.

There is by now a wide variety of actors involved in various ways in each of the three human rights treaty systems under consideration, namely the CEDAW, CRC and CRPD, other than the states parties to the treaty and the committee of experts which comprises the treaty body. Four in particular will be mentioned here. First there are non-governmental organizations or NGOs, local, national and international. Second there are transnational coalitions of NGOs, or regional international networks which coordinate the engagement of members and others with the treaty-body systems. ${ }^{49}$ Third there are national human rights institutions or bodies, ${ }^{50}$ and in the CEDAW context there are specific gender-related national bodies referred to as National Women's Machineries. ${ }^{51}$ Fourth, there are international intergovernmental organizations with specific mandates to promote the rights of women and children, and which work closely with the human rights treaty systems. These are UNICEF in the case of children's rights and the CRC, ${ }^{52}$ and UN Women, ${ }^{53}$ in particular the Commission on the Status of Women,${ }^{54}$ in the case of CEDAW. There is as yet no real analogous organization in the newer regime of the CRDP, although UN Enable, run by the secretariat of the CRPD, is a kind of embryonic support organization for this regime. ${ }^{55}$

There are several key ways in which this array of non-state actors, perhaps most importantly the non-governmental organizations and transnational networks, contributes to the experimentalist functioning of the human rights treaty system. Four particular roles played by NGOs in operationalizing the three human rights treaties under consideration will be outlined here.

(i) The first and most obvious is the practice of NGOs in providing information to the committees during the reporting process. While formally speaking it is the states which are required to produce and submit reports on their performance in terms of compliance with the commitments made under the treaties, NGOs have over time become an important additional source of information for the treaty bodies. ${ }^{56}$ NGOs increasingly submit what are termed 'shadow' reports to the committees, providing alternative sources of information to those of the official government reports about problem issues and areas. Additionally, within those states whose governments are willing to work with NGOs, specialized NGOs supply information and feedback to the government in the preparation of their official reports. ${ }^{57}$ Further, the treaty bodies (the committees of experts)

${ }^{49}$ In the CEDAW context, the most prominent of these is IW-RAW (International Women's Rights Action Watch, www.iwraw.net), in the CRC context it is CRIN (Child Rights International Network, www.crin.org), and in the CRPD context it is the IDA (International Disability Alliance, www.internationaldisabilityalliance.org).

${ }^{50}$ See the 2011 Information Note of the Office of the High Commission for Human Rights on National Human Rights Institutions (NHRIs) Interaction with the UN Treaty Body System, OHCHR Information Note 2011/411.

${ }^{51}$ These were an outcome of the Beijing World Conference on Women, 1995.

${ }^{52} \mathrm{http}: / /$ www.unicef.org/crc/

${ }^{53}$ www.unwomen.org

${ }^{54} \mathrm{http}: / /$ www.unwomen.org/en/csw

${ }^{55} \mathrm{http}: / /$ www.un.org/disabilities/

${ }^{56}$ For critical analysis of the role of NGOs and others in the construction of indicators which are increasingly used to monitor and assess the performance of states under human rights treaties including the ICESCR, see Margaret Satterthwaite and Ann-Jannette Rosga "Trust in Indicators: Measuring Human Rights" (2009) 27 Berkeley Journal of International Law 253. See also see Sally Engle Merry "Measuring the World: Indicators, Human Rights, and Global Governance" (2011) 52 Current Anthropology 583, and "Human Rights Monitoring and the Question of Indicators" in M. Goodale, Human Rights at the Crossroads (Oxford UP, 2014), Chapter 10.

${ }^{57}$ In the UK and Ireland, for example, the Children Rights Alliance NGO plays this role. According to one interviewee [CITE]: "The Children's Rights Alliance is a coalition of participating NGOs which began mainly as a body dedicated to gathering expertise and engaging in shadow reporting, has since grown into an organization of NGOs that provide expertise and information to states parties in the process of reporting to the committee and working to comply with the "concluding observations" of the committee. Working for over 100 national NGOs in Ireland, the coalition has grown well beyond its shadow reporting duties and now uses legal expertise to help direct NGOs that provide services on the 
increasingly hold meetings with civil society actors, including private meetings in advance of the hearings they hold with states during the reporting process, as well as public meetings. More informal meetings and discussions also take place between committee members and NGOs. Such meetings and interactions are significant because NGOs are not allowed to make statements during the hearings held by the committees with states. The role of NGOs in bringing information from the ground to the monitoring committee is a key one from an experimentalist perspective, and it appears that they play a more active role than merely supplying information or identifying issues for the committee, by proposing steps that the committee could recommend governments should take to fulfill their obligations. $^{58}$

(ii) A second role which NGOs have come to play within the three treaty systems is that of following up on the committees' 'concluding observations', which represent the outcome of the treatybody reporting process. ${ }^{59}$ Following the dialogic process during which states submit reports (alongside the NGO shadow reports) on the performance of their treaty obligations, the treaty bodies issue so-called concluding observations which deliver the committee's assessment of the state's performance as well as recommendations for improvement in relation to implementation of the rights in question. NGOs then mobilize to pressurize governments in carrying out the steps indicated in the committee's concluding observations, and organize advocacy and other forms of pressure to encourage governments to abide by them. This regularly includes advocacy for legislative reform, using the media to generate publicity and shame, but also bringing strategic litigation seeking rights enforcement, and more generally facilitating cooperation between various civic forces that seek to implement the committee's recommendations and observations.

(iii) A third role carried out by certain NGOs, which has been prominent in the context of certain provisions of CEDAW and the CRC, is that of cultural translation. ${ }^{60}$ For example, in the case of Islamic states or states with a significant Muslim population, the role undertaken by NGOs includes translating the requirements and provisions of human rights treaties into terms which are more likely to resonate domestically and which may have a better chance of cultural acceptance and internalization. NGOs can play a crucial mediating role between domestic social groups and international norms and bodies, providing two-way translation. On the one hand, the CEDAW, CRC and CRPD provisions may require appropriate cultural translation to render them useful in protecting and promoting the interests of women, children and disabled persons in particular geographic and socio-political contexts. On the other hand, NGOs can provide translation in the other direction also, by informing and advising the committee and supplying it with the relevant information and language with which to counter arguments made by states who seek to rely on local practice, law or custom to justify non-compliance with the Convention. ${ }^{61}$ This kind of role has been described by anthropologist

(Contd.)

ground, which in turn provide the coalition with information on the gaps in the legislative regime and where the state party must be pressured to make reforms".

${ }^{58}$ See.e.g Suzanne Zwingel's discussion of the influence of the International Women's Rights Action Watch, (IRWAW) and IRWAW-Asia on the CEDAW committee, in How do International Women's Rights become Effective Domestic Norms? An Analysis of the Convention on the Elimination of all Forms of Discrimination against Women PhD thesis, Bochum (2005), Chapter 8. And on the ways in which and the extent to which NGOs influence the output of the Committee on the Rights of the Child, see Gamze Erdem Turkelli \& Wouter Vandenhole, The Convention on the Rights of the Child: Repertoires of NGO Participation, (2012) 12 Human Rights Law Review 33, 46

${ }^{59}$ See M. O Flaherty "The Concluding Observations of United Nations Human Rights Treaty Bodies" (2006) 6 Human Rights Law Review 27.

${ }^{60}$ See Sally Engle Merry "Transnational Human Rights and Local Activism: Mapping the Middle" (2006) 108 American Anthropologist 38 and "Vernacularization on the Ground: Local Uses of Global Women's Rights in Peru, China, India and the US" (2009) 9 Global Networks 441.

${ }^{61}$ To quote from an interview with a spokesperson for the NGO Sisters in Islam: "Where we come in is particularly in relation to Article 16 (concerning family life, marriage etc). Much of the challenge for reporting Muslim countries concerns Article 16, given the influence of Sharia law and the Qu'ran. What we want to do here is to say is that this should not give reason to the CEDAW Committee to stop questioning. Sometimes when the Committee is presented with words of this kind (God, Sharia, religion) the Committee does not have any response. We want to give the Committee the language to challenge governments when these arguments are put forward. We want to expand the arguments they can deploy. What we want to do is to say that, because Islam is being used to inform public policy, we will point out the 
Sally Engle Merry as a process of vernacularization of international human rights law, which she exemplifies by examining the successful use of international human rights law and language by indigenous women to challenge female inheritance laws in Hong Kong where the traditional property and family norms of indigenous communities barred female inheritance. ${ }^{62}$

(iv) A fourth role carried out by NGOs in certain contexts includes the provision of direct services to women, children and disabled persons, seeking where they have the necessary capacity and resources to fill the gaps identified through the treaty-body mechanism. This is particularly the case in the least developed countries, ${ }^{63}$ although not only there. ${ }^{64}$

A further important and often complementary set of actors to emerge alongside individual NGOs within international human rights treaty systems are transnational coalitions and networks. ${ }^{65}$ The functions performed by transnational networks such as IWRAW, CRIN and IDA ${ }^{66}$ include the sharing of information and expertise, the provision of information and training on the treaty-body system, mobilizing litigation and other implementation strategies, and bringing relevant groups and people in contact with one another. The role of these networks is particularly significant for states in which civil society is weak, and in which there is a lack of access to adequate information.

CRIN, for example, regularly refers wronged parties - who contact them claiming that a government has violated their rights under the Convention - to local organizations that deal with the particular issues they raise ${ }^{67}$ The network also provides information to individuals and NGOs on the requirements imposed by various states for lodging complaints, and brings different national NGOs together to exchange information and experience on monitoring the treaty within a particular state. It has created general guidelines on how to respond to complaints arising within specific states and has attempted to identify which issues are most problematic for particular states. It also maintains a legal database of lawyers who are willing to offer their services free of charge and which summarizes how the CRC has been treated by national judiciaries, as a resource for domestic groups and individuals to use. This information has also been used by CRIN to shape suggestions and recommendations made to the committee.

IWRAW - created in 1985 following the Third World Conference on Women with a view to publicize and monitor the implementation of CEDAW - similarly functions as a resource and communications center to serve activists, NGOs and researchers internationally. IRWAW sees its role as building and supporting capacity amongst NGOs and within the treaty bodies to promote accountability for women's rights. The organization participates in meetings of the treaty bodies, and develops relationships between international NGOs which are concerned with the human rights treatymonitoring process and other forms of monitoring. There are regional and national branches of IWRAW, some of which, according to personnel interviewed, see themselves as seeking to influence

(Contd.)

diversity of Islamic jurisprudence on these issues... and the heterogeneity of Islamic culture". For examples of this kind of cultural resistance by states, see S Engle Merry "Disjunctures between Global Law and Local Social Justice" in Human Rights and Gender Violence Chapter 4 , (U of Chicago Press, 2006) p. 103.

${ }^{62}$ See e.g. S. Engle Merry and R Stern "The Female Inheritance Movement in Hong Kong: Theorising the Local/Global Interface" (2005) 46 Current Anthropology 387: "Human rights intermediaries put global human rights ideas into familiar symbolic terms and use stories of local indignities and violations to give life and power to global movements. They hold a double consciousness, combining both transnational human rights concepts and local ways of thinking about grievances. They may be local activists, human rights lawyers, feminist NGO leaders, academics, or a host of other people who have one foot in the transnational community and one at home. They are constrained by the human rights discourse and by the cultural meanings of the situation where they are working."

${ }^{63}$ See Defence for Children International, National Impact 33 (2013), on their work promoting the implementation of the Convention in Angola and Cameroon, and also in middle income countries like Colombia.

${ }^{64}$ Interview with Children's Rights Alliance on Ireland and the UK

${ }^{65}$ Margaret Keck and Kathryn Sikkink were amongst the first to draw attention to the important role of these networks in their book Activists Beyond Borders: Advocacy Networks in International Politics (Cornell UP, 1998). See also T Risse and K Sikkink, The Power of Human Rights (2002)

${ }^{66}$ See n.49 above.

${ }^{67}$ Anna Volz, Advocacy Strategies Training Manual: General Comment No. 10: Children's Rights in Juvenile Justice, Defence for Children International 3 (2009). 
and shape the output of the CEDAW committee, while others - particularly within states which lack resources - see themselves as primarily concerned with receiving ('downloading') the output of the committee, and pressurizing for its domestic implementation.

\section{(3) Iteration and revision within UN human rights treaty systems}

In addition to the crucial dimension of stakeholder involvement in the translation of international norms to local contexts and in the provision of information from the local to the international level, the fifth feature of experimentalist systems mentioned above is the existence of an adequate feedback loop; the framework goals and the processes for achieving them are kept open to reconsideration and revision in the light of the information gained and the lessons learned in the process of implementation. The possibility of transnational learning from experience and 'learning from difference' is a major premise of experimentalist governance theory. ${ }^{68}$

While this iterative or reflexive dimension is not a prominent feature of the international human rights system, there are certain iterative dimensions to the system. In the first place, there is an element of reflexivity in the way in which the CEDAW, CRC and CRPD committees operate; civil society actors bring new data and information to the committee, and regularly bring new issues to the attention of the committee and the international community. In the second place, there is within CEDAW a broader mechanism of sorts for reflecting on, and revising or updating, the goals expressed in the text of the Convention. One of the ways in which this has been achieved has been through the four major International Conferences on Women, which took place in Mexico, Copenhagen, Nairobi and Beijing respectively. ${ }^{69}$ Another way has been through the use of 'general recommendations' by the treaty bodies. A key example of this is the issue of violence against women. At the time the CEDAW Convention was being prepared, violence against women was not prominent on the international agenda. ${ }^{70}$ However, the CEDAW Committee later effectively incorporated the issue through the use of general recommendations. ${ }^{71}$ Further, the committee has issued at least twenty-eight general recommendations on issues not specifically covered in the Convention, e.g.: condemning female circumcision, ${ }^{72}$ calling for equal remuneration for work of equal value, ${ }^{73}$ concerning discrimination based on AIDS $;{ }^{74}$ on rights of women in marriage and the family $;{ }^{75}$ incorporating issues of maternal health including family planning into Article 12 of the Convention; ${ }^{76}$ and dealing with states' obligations to migrant women workers. ${ }^{77}$ The impetus for this kind of revision and updating has come from a variety of sources with significant input from NGOs and international bodies.

${ }^{68}$ C. Sabel and J Zeitlin "Learning from Difference: The New Architecture of Experimentalist Governance in the EU" (2008) 14 European Law Journal 271.

${ }^{69}$ See http://www.unwomen.org/en/how-we-work/intergovernmental-support/world-conferences-on-women

${ }^{70}$ Sally Engle Marry, Constructing a Global Law-Violence against Women and the Human Rights System, 18 Law and Social Inquiry 941, 952 (2003).

${ }^{71}$ See CEDAW General Recommendations 12 and 19

${ }^{72}$ See UN Committee on the Elimination of Discrimination Against Women (CEDAW), CEDAW General Recommendation No. 14, 1990, A/45/38 and Corrigendum, available at, http://www.refworld.org/docid/453882a30.html.

${ }^{73}$ UN Committee on the Elimination of Discrimination Against Women (CEDAW), CEDAW General Recommendations No. 13, 1989, A/44/38, available at, http://www.refworld.org/docid/453882aa10.html.

${ }^{74}$ UN Committee on the Elimination of Discrimination Against Women (CEDAW), CEDAW General Recommendation No. 15, 1990, A/45/38, available at, http://www.refworld.org/docid/453882a311.html.

${ }^{75} \mathrm{UN}$ Committee on the Elimination of Discrimination Against Women (CEDAW), CEDAW General Recommendation No. 21,1994, available at, http://www.refworld.org/docid/48abd52c0.html.

${ }^{76}$ UN Committee on the Elimination of Discrimination Against Women (CEDAW), CEDAW General Recommendation No. 24, 1999, A/54/38/ available at, http://www.refworld.org/docid/453882a73.html.

${ }^{77}$ UN Committee on the Elimination of Discrimination Against Women (CEDAW), General Recommendation No. 26, 2008,CEDAW/C/2009/WP, available at, http://www.refworld.org/docid/4a54bc33d.html 
For the Committee on the Rights of the Child, the practice of organizing discussion days ${ }^{78}$ and issuing General Comments ${ }^{79}$ has also been an opportunity to update and integrate new or more specialized issues which have been brought to the committee's attention even if they were not contemplated at the time the Convention was drafted. Another way of responding to new issues arising, and bringing them onto the international agenda, is through the provision in Art 45(c) of the Convention, which allows the committee to recommend that the UN General Assembly request the Secretary General to undertake a study into a particular issue on its behalf. Such a request was notably made in the case of violence against children ${ }^{80}$ It led to the appointment of an expert to conduct a study for the Secretary General, ${ }^{81}$ which led in turn to the creation of a full-time senior UN post, the Special Representative on violence against children. ${ }^{82}$ This was also done in relation to the subject of children in armed conflict, where the CRC Committee invoked Article 45(c) and drew in the UN Secretary General, ${ }^{83}$ a process which resulted ultimately in the creation of a similar UN role focused on children in armed conflict. ${ }^{84}$

And as far as the Convention on the Rights of Persons with Disabilities is concerned, some kind of periodic review and reconsideration is facilitated by the fairly novel provision in Article 40 of the Convention, which provides that 'the States Parties shall meet regularly in a Conference of States Parties in order to consider any matter with regard to the implementation of the present Convention'. While most other international human rights treaties in practice hold a reasonably regular conference of the parties without any explicit provision for such being found in the treaty itself, this is generally done for purely formal reasons - mainly to elect the members of the monitoring committee and other minor housekeeping matters - and substantive matters relating to the treaty are not discussed. By comparison, it seems that the annual conference of the CRPD does entail discussion of substantive questions and is actively attended by NGOs and civil society groups. Further, like the committee under the Children's Rights Convention, the CRPD committee has begun to hold days of general discussion on specific issues, most recently on the right to education, as a consequence of the information brought to the committee through the rights of persons with disabilities. ${ }^{85}$

In sum, the five important elements of experimentalist governance systems are reflected in the UN human rights treaty system, and specifically in the three human rights treaty systems examined here (CEDAW, CRC and CRPD). Most significantly, the dimension of stakeholder participation has developed prominently in recent decades and has transformed the way in which those systems function. ${ }^{86}$

\section{The implications of an experimentalist governance perspective on the international human rights treaty regime}

What are the relevant implications of this experimentalist perspective on these international human rights treaty systems? Three important implications will be outlined here.

\footnotetext{
${ }^{78} \mathrm{http} / / /$ www2.ohchr.org/english/bodies/crc/discussion.htm

${ }^{79}$ See for a collection of the CRC's General Comments www.crim.org/en/library/publications/crc-general-comments

${ }^{80}$ The issue of violence against children is mentioned in Art 19 of the Convention, but mainly in the context of parental violence, sexual abuse and neglect.

${ }^{81}$ Report of the independent expert for the United Nations study on violence against children (A/61/299).

${ }^{82} \mathrm{http}: / /$ srsg.violenceagainstchildren.org/

${ }^{83}$ See the conclusions and recommendations adopted by the Committee on the Rights of the Child at its $20^{\text {th }}$ session, 1998, $\mathrm{CRC} / \mathrm{C} / 19 / \mathrm{Rev} 9$

${ }^{84} \mathrm{http}: / /$ childrenandarmedconflict.un.org/

${ }^{85}$ See www.ohchr.org/EN/HRBodies/CRPD/Pages/DGDontherighttoeducationforpersonswithdisabilities.aspx

${ }^{86}$ For a richly comprehensive account of the functioning of the CEDAW regime which effectively supports the argument that that treaty system operates in an experimentalist way, see S. Zwingel, How do International Women's Rights become Effective Domestic Norms? An "Analysis of the Convention on the Elimination of all Forms of Discrimination against Women" PhD thesis, Bochum (2005)
} 
A first is that it draws attention to, and presents a fuller and more nuanced picture, of the operation of UN human rights treaties, and provides a somewhat different causal account of their effectiveness, than many existing accounts. (ii) A second is that it provides a robust response to some of the critiques of the human rights treaty system introduced earlier. (iii) Third, it suggests possible avenues for reform of these and other existing human rights treaty systems with a view to making them more effective in practice.

An experimentalist perspective on treaty systems such as CEDAW, CRC and CRPD widens the lens through which the human rights treaty systems are viewed. It focuses attention beyond the two main official sets of actors - state governments and treaty bodies - and beyond the formal engagement of the state with the expert committee, to include the growing array of local, national and international non-governmental actors and institutions and the way they inform, implement and give shape to the regime and to the treaty in practice. Without overlooking the crucial interactions of state actors with the treaty bodies, the experimentalist governance perspective also focuses attention on the significance of other actors and their activities to the implementation and realization of the norms contained in the treaties. It highlights the way in which the rise and integration of many non-state actors has changed the bilateral and formal nature of the inter-state monitoring regime in significant ways: by providing alternative sources of information; by ensuring closer understanding of problems on the ground; by supplying localized knowledge of particular issues and challenges in different areas and regions; by suggesting alternative discourses and ways of supplementing or challenging state reporting; by connecting local actors and entities with transnational networks; by building capacity, providing training, mobilizing advocacy and proposing practices and strategies to activate change; and by proposing, or even in some cases supplying, solutions by providing direct services. Viewed from an experimentalist perspective, the human rights treaty-body system resembles less the critical depiction of a distant bureaucratic regime peopled by underfunded and ineffectual committees, and more a dynamic regime involving multiple actors and bodies at different levels - local, national, regional and transnational - engaged in tackling a wide range of human rights issues, placing neglected issues on the agenda, and devising, proposing and sometimes implementing solutions. Through their awarenessraising, information-sharing, advocacy, service-delivery, vernacularization and two-way translation, NGOs, civil society actors and others activate UN human rights treaty systems such as the CEDAW, CRC and CRPD and are instrumental in transforming them into more participatory and accountable experimentalist governance systems.

And while there is a richer political science literature - including theories such as the 'boomerang effect' and the role of transnational networks ${ }^{87}$ - which draws attention to the role of domestic civil society and transnational actors in mobilizing for human rights, experimentalist governance theory points to the crucially iterative and mutually constitutive relationship between the global norm and its local contextualization. It is not just that human rights treaties become effective because international NGOs can supply pressure from outside to prod resistant domestic governments, or because local actors can invoke international norms in demanding or advocating for change. Rather, the most important dimension is the ongoing interaction between the global and the local with each being dependent on the other for the development of the norm and its realization in practice over time and in different contexts. It is not that international norms are gradually sharpened and imposed onto the state and the population below, or that local actors make whatever they want of international norms in specific settings. Instead, experimentalism posits that open-ended but important global norms only take shape through their implementation in different local contexts by a varied array of actors, governmental as well as non-governmental; and that the locally situated actors rely on both the impetus supplied, as well as the opportunity for exchange offered, by the periodic engagement with the treaty body and its output. Some suggestive examples of this iterative engagement over time are provided in the literature, such as the gradual evolution in relation to reproductive rights in Colombia

\footnotetext{
${ }^{87}$ T. Risse, S. Ropp and K. Sikkink, The Persistent Power of Human Rights (CUP, $2^{\text {nd }}$ edn, 2013, $1^{\text {st }}$ edn, 1999), M. Keck and K. Sikkink, Activists Beyond Borders: Advocacy Networks in International Politics (Cornell UP, 1998)
} 
through various cycles of the CEDAW committee process, ${ }^{88}$ and the acceptance of children's participation in school decision-making in the UK through various cycles of the Children's Rights Committee process. ${ }^{89}$

An experimentalist perspective on the functioning of UN human rights treaty systems also provides a possible explanation for the findings of the empirical studies surveyed above, namely that ratification of human rights treaties has a positive impact on human rights standards within states in which there is a reasonably active civil society. What is it about the existence of an active civil society that makes it more likely that a treaty signed by a state will make a positive difference in terms of human rights standards? Experimentalist governance theory suggests that an important way in which a transnationally or internationally established set of standards can be effectively implemented is through the interaction of locally situated, adequately incentivized, resourced and informed actors with an independent center or focal point such as a treaty body, through an iterative two-way process of reporting, monitoring and feedback.

The second relevant implication of an experimentalist perspective on international human rights treaty systems is that it provides a robust response to several of the critiques mentioned earlier. Those criticisms concerned the ambiguity and lack of specificity of human rights standards, the weakness of international human rights enforcement mechanisms, ${ }^{90}$ the claim to universalism and the top-down imposition of one-size-fits-all standards on diverse parts of the world. ${ }^{91}$

Take first ambiguity. While critics have decried the open-endedness and lack of specificity of the standards set out in human rights treaties, such open-endedness is an essential component for the effective operation of experimentalist governance. Experimentalist premises require the original agreement on framework norms to leave sufficient room for local discretion and flexibility in application and adaptation to circumstance. If norms are too prescriptive or too narrow, they are likely to thwart the possibility of adjustment to different circumstances and unlikely to give relevant stakeholders the necessary room to adapt norms to varying contexts and report back on their results.

Take secondly the weakness of enforcement mechanisms. The weakness of human rights treaty mechanisms is said to lie in the fact that they provide only a system of self-reporting by states, with a soft form of shaming using non-binding treaty-body observations and recommendations which are often carefully and diplomatically phrased. Calls have been made by human rights activists, by members of treaty bodies, by UN special rapporteurs, and others to acknowledge or confer binding authority on the interpretative statements of the UN human rights treaty bodies, ${ }^{92}$ and to establish a world court of human rights. ${ }^{93}$ It is argued that international human rights norms, unlike domestic constitutional norms, are ineffectual without a court which is empowered to resolve ambiguities and sharpen authoritative interpretations. ${ }^{94}$

${ }^{88}$ Debra Liebowitz and Suzanne Zwingel, "Gender Equality Oversimplified: Using CEDAW to counter the Measurement Obsession” (2014) 16 International Studies Review 362

${ }^{89}$ Laura Lundy, "Children's rights and educational policy in Europe: the implementation of the United Nations Convention on the Rights of the Child", (2012) 38 Oxford Review of Education 393, 407

${ }^{90}$ See E Posner, The Twilight of Human Rights: "the task of interpreting and defining these vaguely worded rights - unlike in domestic settings is not given to a court with authority to decide - but instead to international institutions that have deliberately been created to be very weak".

${ }^{91}$ E Posner, id: "International human rights law ...reflects the same basic civilizing ideology combined with a top down mode of implementation... It fails... to grapple with the huge variation among states and their extreme complexity".

${ }^{92}$ See for example on the ICCPR, the arguments of Manfred Nowak in The UN and its Covenant on Civil and Political Rights: CCPR Commentary (Engel, $2^{\text {nd }}$ edn, 2005) 668, and Martin Scheinen "The Work of the Human Rights Committee under the ICCPR and its Optional Protocol" in Raija Hanski \& Martin Scheinin (eds.), Leading Cases of the Human Rights Committee (Turku: Abo Academi, $1^{\text {st }}$ edn, 2003), 22

${ }^{93}$ Martin Scheinen Towards a World Court for Human Rights

http://www.eui.eu/Documents/DepartmentsCentres/Law/Professors/Scheinin/WorldCourtReport30April2009.pdf (and forthcoming). For a response see P Alston "Against a World Court for Human Rights" (2014) 28 Ethics and International Affairs 197.

${ }^{94}$ E Posner, The Twilight of Human Rights, chapter 5. 
From an experimentalist governance perspective, however, the existence of a court whose function is to hand down authoritative and binding rulings on the meaning of specific terms is not a necessary element of an effective governance system and indeed could even thwart it. While courts are certainly compatible with experimentalist governance systems, their role is not necessarily to close off all ambiguity or to authoritatively resolve issues of interpretation in a single final direction. Instead, a court within an experimentalist governance system can be understood as a catalyst for reform, ${ }^{95}$ or as a destabilizer of dysfunctional arrangements. ${ }^{96}$ Hence the absence of an authoritative court or body - such as a treaty body - which could close off the possibility for differential interpretation and application in different local contexts of the meaning of a single human rights norm is quite compatible with, and even required, by the tenets of experimentalist governance. Yet the lack of such binding, hierarchical enforcement in the human rights domain has met with much criticism and the non-binding, discursive nature of the treaty-body system has been the object of complaint. ${ }^{97}$ Human rights NGOs, scholars and others have indeed often been highly skeptical of the suggestion that a human rights system may not need, or may not be best served, by binding hierarchical enforcement. ${ }^{98}$ What is there, they reasonably ask, to constrain states from adopting whatever meaning they like, avoiding any real influence or impact of the obligations they have undertaken to protect and promote human rights, and choosing to interpret them in a self-serving way which avoids the need for any change? The answer of experimentalist governance theory is that it is the presence of an active, engaged array of stakeholders with an interest in enforcing the human rights norm, combined with the obligation of regular state reporting alongside stakeholder monitoring and reporting back to the center, which provides a fairly robust safeguard against a self-interested interpretation of human rights norms by states which seek to avoid action and accountability. What prevents states from ignoring their commitments or hiding their noncompliance is the obligation of periodic and regular reporting, accompanied by NGO shadow-reporting to an external body which conducts a kind of nonhierarchical review. The Treaty bodies engage in dialogue with states; informed by the reports and prior participation of NGOs in preparing for the dialogue. They issue recommendations and observations on the responses of the states, and these observations and recommendations themselves become part of the iterative process by being taken up at domestic level by actors who seek to use them to shape change. ${ }^{99}$

Take then the objection to the supposedly top-down imposition by human rights systems of a uniform standard on diverse parts of the world. Critics allege that treaty-based human rights norms are abstract standards imposed in a uniform way by elites without regard to the diversity of different parts of the globe or to the varying needs and wishes of local populations. ${ }^{100}$ An experimentalist account of UN human rights treaty systems, however, rejects the idea of top-down governance as both undesirable in principle and unworkable in practice. On the contrary, each level or layer in a multilevel experimentalist system is dependent on the other for the effective functioning of the system as a whole, and for the shared goals to be effectively pursued. The 'center' (in this case the conference of states which enacted the treaty and the treaty body or committee which is charged with monitoring its enforcement) relies heavily on the local or contextually situated actors to adapt,

\footnotetext{
${ }^{95}$ Joanne Scott and Susan Sturm "Courts as Catalysts" (2006) 13 Columbia Journal of European Law 565.

${ }^{96}$ C Sabel and W Simon “Destabilizing Rights” (2004) 117 Harvard Law Review 1015

${ }^{97}$ See nn 92 and 93 above.

${ }^{98}$ See however P Alston, “Against a World Court", n93 above.

${ }^{99}$ See however the argument of Andrew Guzman and Katerina Linos in "Human Rights Backsliding" (2014) California Law Review that international human rights norms and standards are sometimes used within domestic political debates to cut back on existing rights and standards rather than to promote new protections. They argue that in advanced democracies with substantial domestic protection for human rights, governments sometimes cite the 'minimum standards' set by international human rights courts as an argument to support their move to reduce some unpopular benefit (e.g. parental leave in Sweden), or to bolster their decision to change a particular rule of evidence (the non-admissibility of purely hearsay evidence in the UK). See also Jason Mazzone, using the same example of hearsay evidence in "The Rise and Fall of Human Rights" (2014) 3 Cambridge Journal of International and Comparative Law 929.

${ }^{100}$ See $n 7$ above.
} 
interpret, enact, implement, and report back on the operation of the norms in particular sites and contexts. At the same time the local and intermediate levels rely on the center to ensure ongoing scrutiny and reflection on the results achieved in light of information drawn from different contexts and sources, and more generally to help promote the transparency and accountability of the system as a whole. The very open-endedness of the framework norms, which are criticized by some as hopelessly ambiguous, is important to prevent a centralized top-down approach and to leave ample room for adaption to circumstance.

The third and final implication of an experimentalist perspective on human rights treaty systems is that it points to possible avenues for reform of existing human rights treaty systems with a view to making them more effective in practice. Specifically, it is clear that an international human rights treaty system requires the integral involvement of locally situated domestic actors, NGOs and intermediaries, such as national human rights institutions, as well as the support of transnational networks and international bodies that advise and provide information, particularly where domestic civil society is weak and lacks access to information. Adequate channels of communication and exchange between the international review body and the array of state and non-state actors are necessary.

It appears, however, that states are growing increasingly resistant to external monitoring of their human rights practices and to the involvement of civil society in such processes. Two recent trends illustrate this. In the first place, human rights NGOs have been under attack in a range of states, and not only in states that have been historically the most repressive towards civil society. ${ }^{101}$ In the second place, in recent negotiations over the UN sustainable development goals, a range of states have been resistant to allowing the participation of civil society, ${ }^{102}$ and in particular have resisted civil society involvement in any proposed review and monitoring mechanisms, and have insisted on domestic governmental control over the sources and nature of data provided to the review body established. ${ }^{103}$ And while the sustainable development goals (SDGs) scrupulously avoid using the language of human rights, the commitments undertaken by states in the SDGs overlap significantly with many of their existing human rights commitments.

These trends could be interpreted as an ominous sign and an indication of the likely future marginalization of non-state actors and civil society groups in the international human rights regime, but they could also be seen as a reflection of the success and effectiveness of civil society involvement in human rights treaty implementation and monitoring. And while the immediate political climate may not appear propitious, the history and record of civil society groups such as human rights NGOs suggests that they are resilient and adaptive, and unlikely to disappear as a result of the enactment of repressive laws, or to cease their efforts to be centrally involved in human rights treaty implementation. It seems far more likely that NGOs will find alternative ways of organizing and operating within repressive states until such time as the political climate becomes less hostile, and that, just as in the case of CEDAW and the Convention on the Rights of the Child which did not provide any role for NGOs or other non-state actors in the human rights regime, civil society groups will continue to mobilize and to find ways of acting strategically, and engaging actively, with international human rights systems and other overlapping regimes such as the Sustainable Development agenda. The argument of this paper is that the effectiveness of those systems in improving human rights standards domestically will depend in significant part on the integration and activity of such stakeholders within a participatory and iterative system of the kind described above.

\footnotetext{
${ }^{101}$ Harriet Sherwood, "Human Rights Groups Face Global Crackdown not seen in a Generation", The Guardian, 26 August, 2015: http://www.theguardian.com/law/2015/aug/26/ngos-face-restrictions-laws-human-rightsgeneration?CMP=share_btn_wa

${ }^{102}$ See e,g, the Open Letter written by "representatives of the major groups and stakeholders of civil society" who had been registered to participate in the UN 'Open Working Group' on the SDGs, https://sustainabledevelopment.un.org/content/documents/10404openletter.pdf

${ }^{103}$ See the High Level Political Forum, https://sustainabledevelopment.un.org/hlpf/2015
} 

